\title{
電析法による非晶質 Fe-Ni-P合金の作製
}

\author{
李 \\ 明*, 小若 正 倫*
}

\author{
Preparation of Amorphous Fe-Ni-P Alloys by Electrodeposition
}

\author{
Ming $\mathrm{LI}^{*}$ and Masamichi KOWAKA*
}

\begin{abstract}
Amorphous Fe-Ni-P alloys were prepared by electrodeposition from a 1-hydroxyethane-1, 1-diphosphonic acid bath. The effects of bath composition on alloy composition and on the range of alloys obtainable in amorphous form were investigated. Because of the surface active property of 1-hydroxyethane-1,1-diphosphonic acid, the surface of the deposited alloy was smooth and bright, and the critical concentration of phosphorus in alloys in amorphous form was relatively low. The critical $\mathrm{P}$ concentration was also lowered from $7.6 \%$ by weight to some $5 \%$ when the iron content of the deposit was increased to $60 \%$ by weight.
\end{abstract}

Key Words : Electrodeposition, Fe-Cr-Ni-P Alloys, Amorphous

\section{1. 緒言}

非晶質 Ni-P合金めっき膜は塩酸中で優れた耐食性を 示し ${ }^{1)}$, また良好な耐摩耗性 ${ }^{2)}$ や, 被覆下地の疲労強度 を向上させる ${ }^{3)}$ な゙の特性を有し, 古く ${ }^{4)}$ 加良く研究 され，応用されてきた。しかし非晶質 Fe-P及び Fe-Ni$\mathrm{P}$ 合金めっきに関する研究報告は極めて少ない。奈賀 $5^{5)}$ は液体急冷法によって作製した Fe-Ni-C非晶質合金が 不動態化できず, また化学反応活性のために腐食速度が 純鉄より大きくなることを示している。これが Fe-P非 晶質合金めっきに関する研究が少ない理由と思われる。

しかし, Fe-Ni 合金めっき膜は高い平滑性と硬さを有 し，またNiめっき膜に匹敵する耐食性を示すことが分 かっており, 光沢 $\mathrm{Ni}$ めっきの代替として応用されてい $3^{6)}$ 。一方, $\mathrm{Fe}-\mathrm{Ni}$ 合金系, 特にパーマロイがコンピュ 一夕の記憶素子や, 磁気へッド材料などの軟磁性材料と して使われていることは広く知られている。また高保磁 力を有する Co-Ni-P非晶質めっき膜はコンピュータの 外部記憶装置用のめっきディスクとして利用されている が, そのめっき浴中には, 鉄イオンが $100 \mathrm{ppm}$ 程度存在 すれば Co-Ni-P皮膜の保磁力は急激に低下することが 報告されている7 )。換言すれば, Fe-Ni-P非晶質合金めっ き膜中低保磁力（軟磁気特性）を有するかむしれない。 すなわち Fe-Ni 合金中に Pを加えれば，めっき膜は非 晶質化し, 耐食性と機械的性質の両方を向上させるばか りではなく, 磁気特性を变更することも可能であると考 えられる。これが本研究で Fe-Ni-P非晶質合金めっき 膜の作製について検討する理由である。

従来, クエン酸や酒石酸を含む酸性浴が $\mathrm{Fe}-\mathrm{Ni}$ 及び

*上村工業(㑣)中央研究所 (厂573 大阪府枚方市出口1-5-1)

Central Res. Lab., C. Uyemura \& Co., Ltd. (5-1, Deguchi 1-chome, Hirakata-shi, Osaka 573)
Fe-Ni-P合金めっきに用いられている8)が, Fe-Ni 合 金陽極による溶液組成の制御が難しく，また二価鉄イオ ンの酸化が避け難い。しかしアルカリ性浴の場合には不 溶性陽極が使用でき，三価鉄イオンから直接電析し，か つ皮膜の非晶質化が容易である。また Fe-Ni めっきで はめっき浴中の錯化剤によって得られた皮膜の構造, 光 沢性, 非晶質化の条件などが異なる。たとえば, 界面活 性を有する錯化剤の使用はめっき膜の結晶を微細化し, 皮膜の光沢性と非晶質化条件を改善するようになる。

本報告では，1-ヒドロキシェタン-1, 1-ジホスホン酸 （以後 HEDPと称する）を錯化剤とするアルカリ性浴で の Fe-Ni-P合金めっきを試み, 皮膜の作製条件と非晶 質化の範囲を明らかにした。

\section{2. 実験方法}

用いた電解浴組成は $-\mathrm{FeCl}_{2} \cdot 4 \mathrm{H}_{2} \mathrm{O}$ を $10 \sim 40 \mathrm{~g} / \mathrm{L}$, $\mathrm{NiCl}_{2} \cdot 6 \mathrm{H}_{2} \mathrm{O}$ 20 40g/L, $\mathrm{NaH}_{2} \mathrm{PO}_{2} \cdot \mathrm{H}_{2} \mathrm{O}$ を 2 $\sim 25 \mathrm{~g} / \mathrm{L}, \quad\left(\mathrm{NH}_{4}\right)_{2} \mathrm{HC}_{6} \mathrm{O}_{7} \mathrm{H}_{5}$ を $80 \mathrm{~g} / \mathrm{L}, \mathrm{HEDP}$ 40〜 $60 \mathrm{~g} / \mathrm{L}$ 添加したものである。いずれの試薬す一級試薬を イオン交換水に溶解してめっき浴を調整した。 $\mathrm{KOH}$ 浴に加えて所定の $\mathrm{pH}$ 值に調節した。電解条件は, 浴温

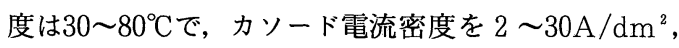
そして浴 $\mathrm{pH} 4$ ～9 の範囲で変化させた。また必要に 応じて浴中の塩化第一鉄と次亜リン酸ナトリウムの代わ りに塩化第二鉄と亜リン酸を用い，皮膜組成に及ぼすそ れらの影響について調べた。陰極試料として厚さ 0.2 $\mathrm{mm}$, 直径 $25 \mathrm{~mm}$ の円形銅板を脱脂, 酸洗して用いた。 また白金被覆チタン網を不溶性陽極として使用した。電 解槽を恒温槽中に設置し, 定電流法でめっきをおこなっ た。種々の電解条件で得られた合金膜の構造をX線回折 $(\mathrm{CuK} \alpha)$ 法によって検討し，その内ブロードな回折図 形の得られるものを非晶質構造と判定した。合金膜の組 


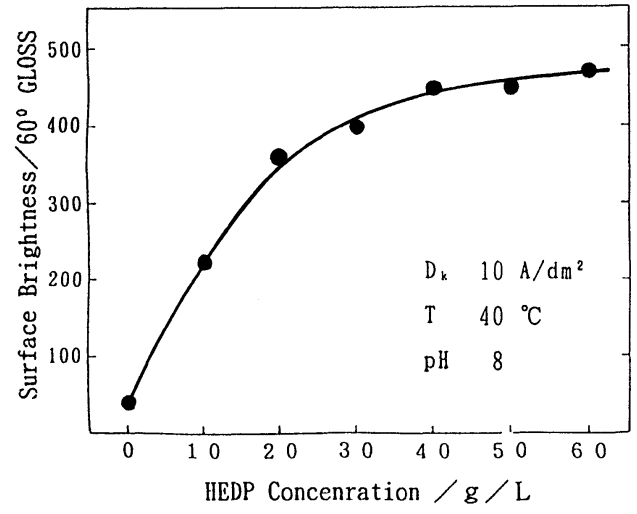

Fig. 1 Effect of the HEDP concentration on the surface brightness of alloy deposits.

成は原子吸光法と蛍光X線分析法を併用して分析した。 皮膜の表面光沢度は日本電色工業(侏製装置を用いて評価 した。

\section{3．実験結果と考察}

\section{1 皮膜の光沢性}

図1に皮膜の表面光沢度に及ぼす HEDP 添加量の影響 を示す。この実験での電流密度は $10 \mathrm{~A} / \mathrm{dm}^{2}$ で $\mathrm{NaH}_{2} \mathrm{PO}_{2}$ ・ $\mathrm{H}_{2} \mathrm{O}$ が $10 \mathrm{~g} / \mathrm{L}, \quad\left(\mathrm{NH}_{4}\right)_{2} \mathrm{HC}_{6} \mathrm{O}_{7} \mathrm{H}_{5}$ が $80 \mathrm{~g} / \mathrm{L}$ であり, $\mathrm{pH} 8$ に固定し, HEDPの濃度のみを変化させた。そ の結果, 図 1 加ら HEDP含有量の増加につれて皮膜の 表面光沢性が著しく向上することが分かる。

HEDPの性質はピロリン酸と類似するが，高温，高 $\mathrm{pH}$ 浴中で安定であり, 分解しない。また有機ホスホン 酸の HEDPは分子の中に- $\mathrm{CH}_{3}$ を含み, 多少の界面吸 着特性を持っている ${ }^{9)}$ 。従って, 浴中の HEDP濃度が 増加すれば, 陰極表面上に一- $\mathrm{CH}_{3}$ が吸着し, 電析物の 平滑度が良くなり, 結晶粒子が微細化し, 皮膜の表面光 沢性を向上させると考えられる。

本実験で HEDPの添加しない浴は，二価金属イオン と HEDPとの形成した錯体が結合しやすい ${ }^{9)}$ から，電 解とともに沈殿が生じる。その防止のため, 浴中に第二 錯化剤としてクエン酸を添加しなければならない。更に, その錯体と浴 $\mathrm{pH}$ を安定にするために, $\mathrm{K}_{2} \mathrm{CO}_{3}(\mathrm{pH}=$ $7 \sim 9$ 場合）あ添加した。

\section{2 合金膜組成におよぼす電解浴組成の影響}

図 2 に示すように, $\mathrm{Ni}$ の共析にとって $\mathrm{NH}_{4}{ }^{+}$の存在 は重要である。すし $\mathrm{NH}_{4}{ }^{+}$がなければ，電流効率は低く なるとともに，皮膜の光沢性も悪くなる。浴 $\mathrm{pH} か ゙$ 高い 場合, HEDPによって形成された $\mathrm{Ni}$ 錯体の安定性が悪 く，そのため電析し難くなるが, $\mathrm{NH}_{4}{ }^{+}$が存在すると $\mathrm{NH}_{4}{ }^{+}$のサイズが小さいため, $\mathrm{Ni}^{2+}$ は放電しやすいアン ミン混合体を形成し ${ }^{10)}$, 皮膜中の $\mathrm{Ni}$ 含有量が増加する

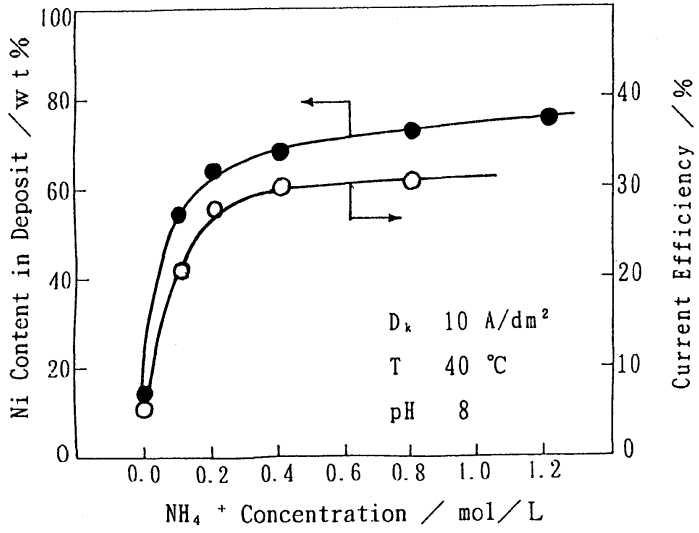

Fig. 2 Effect of the $\mathrm{NH}_{4}{ }^{+}$concentration on the nickel content in deposited alloy and the current efficiency $\left(\zeta=\zeta_{\mathrm{Fe}}+{ }_{\mathrm{Ni}}\right)$.

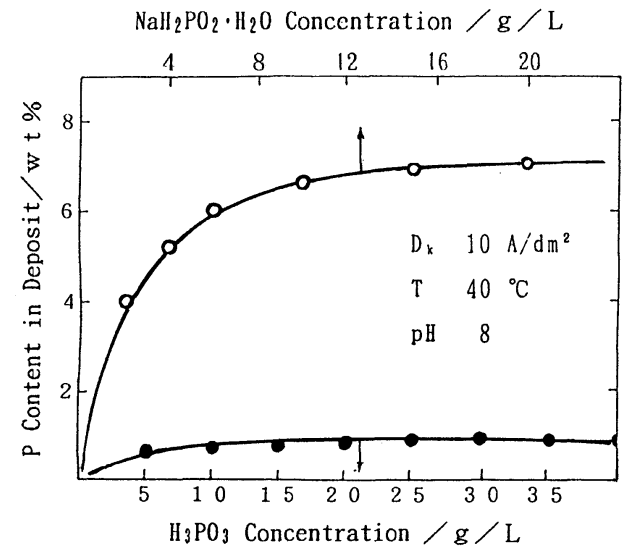

Fig. 3 Effect of the concentrations of sodium hypophosphite (1) and phosphorus acid (2) in the bath on the phosphorus content in deposited alloy.

と思われる。従って，本めっき浴では $\mathrm{NH}_{4}{ }^{+}$の添加が必 要である。図 2 に示す結果から浴中の $\mathrm{NH}_{4}{ }^{+}$濃度が 0.4 モル/L以上になれば，皮膜組成はほぼ一定になる。こ の結果から浴中のクエン酸の代わりに, クエン酸水素二 アンモニウムを用いることにした。

図 3 は合金中の $\mathrm{P}$ 含有量に及ぼす浴中の次亜リン酸ナ トリゥム及び覀リン酸濃度の影響を示す。亜リン酸は酸 性浴 $(\mathrm{pH}=2 \sim 4)$ 中で使用される(10)が，図 3 に示す ように, アルカリ性（ $\mathrm{pH}=7 \sim 10 ）$ 浴の場合, 亜リン

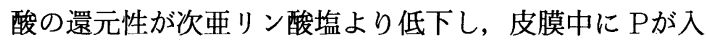
り難く, $1 \mathrm{wt} \%$ 以下に限る。そのためアルカリ性浴で はリンの合金化剤として次亜リン酸塩を選んだ。

本実験の場合，不溶性陽極である白金被覆チタン網を 用いたので, 電解に伴って浴中の $\mathrm{Fe}^{2+}$ が酸化し, 皮膜 組成に影響を及ぼす恐れがある。従って， $\mathrm{Fe}^{2+}$ および $\mathrm{Fe}^{3+}$ を含む浴から得られた合金の組成に対する次亜リ ン酸塩濃度の影響を調べた。その結果を図 4 (a), (b) に 
示す。この実験での電解条件と浴組成は図 3 と同じであ るが，(a) は $\mathrm{Fe}^{2+}$ であり，(b) は $\mathrm{Fe}^{3+}$ ののである。こ れらの両方の浴から得られた皮膜の組成の差はあまり大 きくない。実は，不溶性陽極を使用する場合，浴中の $\mathrm{Fe}^{2+}$ は不溶性陽極の表面で酸化し, $\mathrm{Fe}^{3+}$ は陰極の表面 で一部分は $\mathrm{Fe}^{2+}$ に還元し，電解するとともに，浴中の $\mathrm{Fe}^{2+}$ と $\mathrm{Fe}^{3+}$ 濃度の比は一定になる。但し， $\mathrm{Fe}^{3+}$ を用い る時，還元性的な次亜リン酸塩の消耗量を増加させるの で，前者を用いる方が良いであろう。

\section{3 皮膜組成に及ぼす電解条件の影響}

図 $5(\mathrm{a}),(\mathrm{b})$ および (c) はそれぞれ陰極電流密度，浴温 度および浴 $\mathrm{pH}$ の皮膜組成に及ぼす影響を示す。 2 〜 $\mathrm{A} / \mathrm{dm}^{2}$ の範囲では電流密度の増加とともに, 皮膜中の $\mathrm{Fe}$ 含有量が上昇し，また P含有量が低下するが， $7 \mathrm{~A}$ $/ \mathrm{dm}^{2}$ 以上になると，皮膜組成はほぼ安定する（図 5 (a) 参照)。

図 5 (b), (c) に示すように, 浴温度 $30 \sim 80^{\circ} \mathrm{C}$, 浴 $\mathrm{pH}$ $4 \sim 9$ の広い範囲に渡り, 皮膜組成はほとんど変化しな い。また目視による皮膜の表面光沢性す保持されていた。 しかし低 $\mathrm{pH}$ 浴の場合は，浴が沈殿する恐れがある ${ }^{9}$ の で $\mathrm{pH}$ は 7.5 8.5である方が望ましい。

\section{4 皮膜の非晶質化条件}

3. 4. 1 非晶質化之浴組成の関係

図 6 に浴中の金属イオンの総量及び鉄イオンの含有率 $[\mathrm{Fe} /(\mathrm{Fe}+\mathrm{Ni})]$ と合金皮膜の非晶質化の関係を示す。

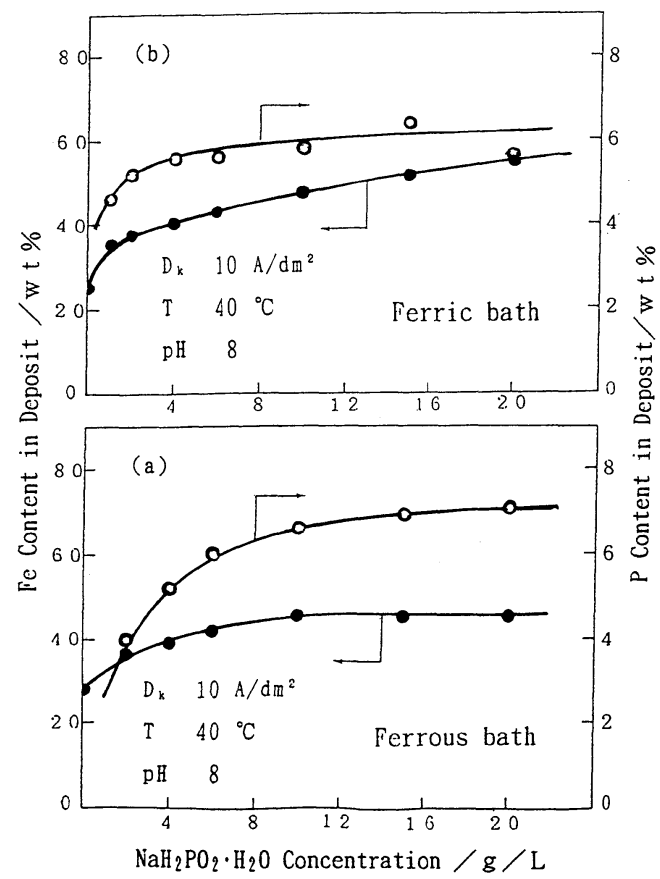

Fig. 4 Effect of the sodium hypophosphite concentration on the alloy composition deposited from the ferric and the ferrous baths.
その他のめっき条件は陰極電流密度は $10 \mathrm{~A} / \mathrm{dm}^{2}$, 浴温 度は $40^{\circ} \mathrm{C}$ で, 浴 $\mathrm{pH}$ は 8 , 浴中の次亜リン酸ナトリウム

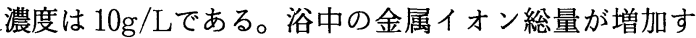
るととあに，浴中の $\mathrm{P}$ 含有率が低下するため，皮膜中の P含有量も減少し, 皮膜は非晶質構造から結晶質構造に 変化する。また浴中の Feイオンの総含有率を $25 \mathrm{wt} \%$ よ り高くすれば，非晶質化の範囲は狭くなる。これは浴中 の Feイオン総含有率が高い場合, 浴中の金属総濃度の 增加に伴って, 皮膜中の $\mathrm{P}$ 含有量がより速く減少するか らである。従って非晶質合金を得るためには次亜リン酸 ナトリゥム濃度が $10 \mathrm{~g} / \mathrm{L}$ と一定の場合には，浴中の金 属イオン総濃度を $20 \mathrm{~g} / \mathrm{L}$ 以下に抑えることが好ましい。

3. 4. 2 非晶質化と皮膜組成の関係

皮膜の合金組成は膜の構造を変化させる重要因子であ る。他の多くの因子は合金組成に影響するが，膜構造の
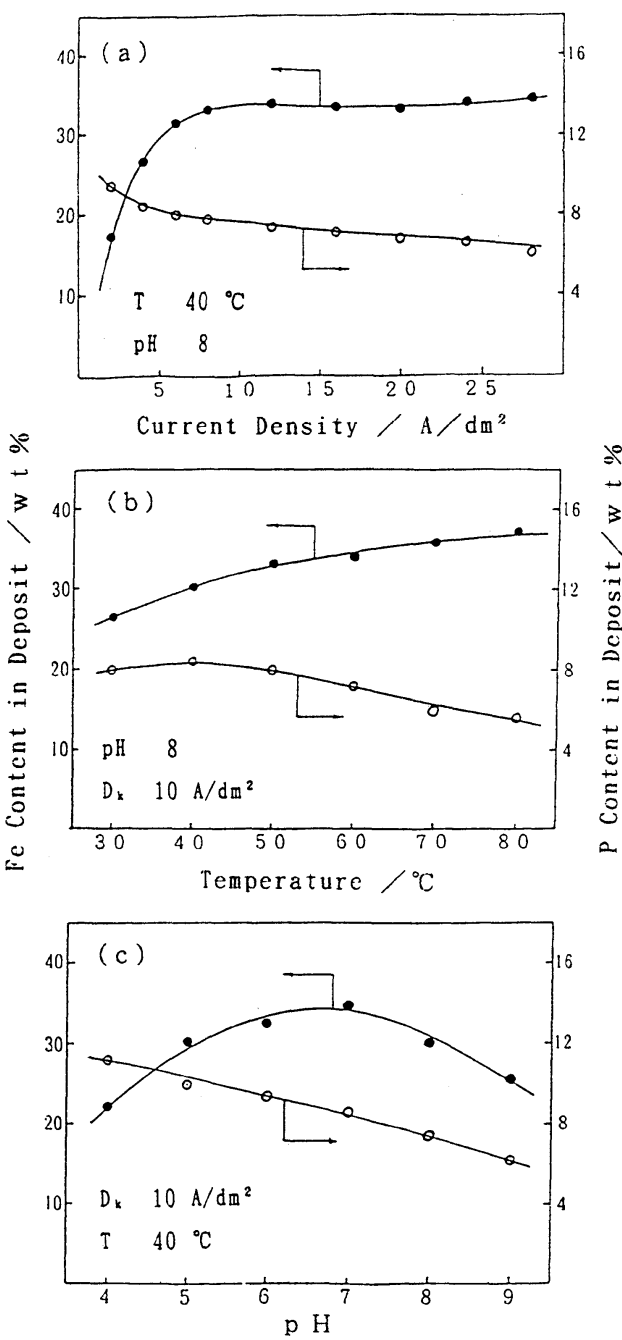

Fig. 5 Effect of the operating conditions on the alloy composition (a) cathodic current density, (b) temperature, and (c) $\mathrm{pH}$. 


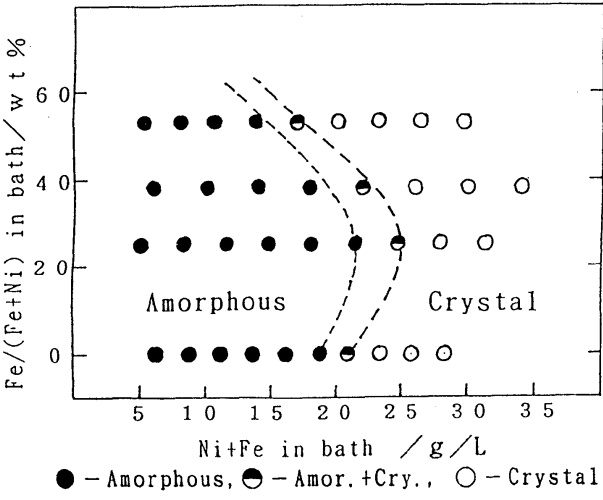

Fig. 6 Relationship between the alloy structure and the bath composition.

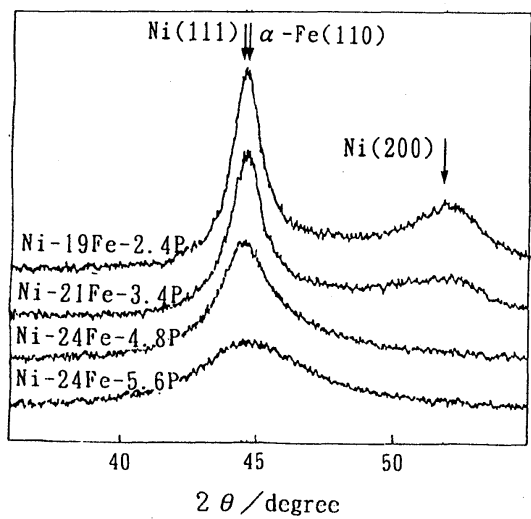

Fig. 7 X-ray diffraction $(\mathrm{Cu} \cdot \mathrm{K} \alpha)$ patterns of Fe-Ni-P alloy deposits containing different amount of phos phorus.

変化に対しては間接的な影響である。ここでは非晶質化 と皮膜組成の関係を中心に検討した。

図 7 に合金の構造に及ぼす皮膜中の P 含有量を示す。 $24 \mathrm{wt} \% \mathrm{Fe}$ 合金膜で P含有量を $5.6 \mathrm{wt} \%$ 以上にすれば X 線回折像はブロードな図形となり，非晶質構造に向かう ことを示す。この含有量はこれまでに報告されてきた $\mathrm{Ni}-\mathrm{P}$ 合金めっき膜の非晶質化条件 $(8 \sim 10 \mathrm{wt} \%)^{11)}$ よ り低い。このことは次の二つの原因によると思われる。 すなわち,

（1）HEDPは界面活性を有し，それらの結晶粒子微細化 への役割があるので，皮膜が非晶質化しやすくなる。

(2) Fe-Ni 合金の場合はいずれのめっき条件で得られた あのあ結晶質構造であるにあかかわらず，鉄とニッケル の原子サイズの差, 及びアルカリ性浴で鉄イオンの電析 難易などの影響因子が存在するので，合金元素を増した 三元合金めっきのみ，鉄により非晶質化が促進される。 この理由で，まず，同様の浴組成と電解条件で作製し た Ni-P合金膜の構造を調べた，その結果を図 8 に示す。

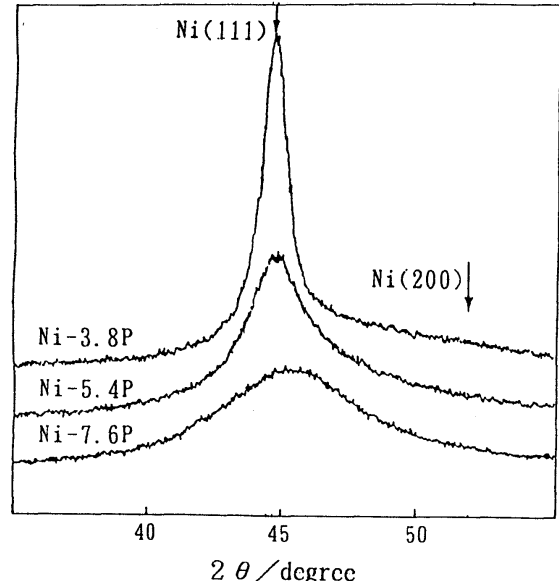

Fig. 8 X-ray diffraction $(\mathrm{Cu} \cdot \mathrm{K} \alpha)$ patterns of Ni-P alloy deposits containing different amount of phosphorus.

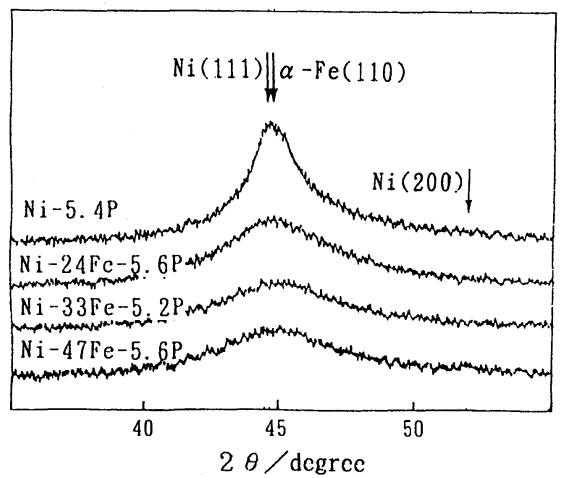

Fig. 9 X-ray diffraction $(\mathrm{Cu} \cdot \mathrm{K} \alpha)$ patterns of $\mathrm{Fe}-\mathrm{Ni}-\mathrm{P}$ alloy deposits containing different amount of iron

この図から Ni-P合金膜は非晶質化に必要な P含有量が だいたい 7.6wt\%で，Fe-Ni-P合金より 2 wt\%高くて, 文献 ${ }^{11)}$ と比べ，まだ低い。

図 9 に Fe-Ni-P合金膜の非晶質化に及ぼす皮膜中の Fe含有量の影響を示す。図に示しているように, 皮膜 中の $\mathrm{P}$ 含有量が一定の時 $\mathrm{Fe}$ 含有量が増加すると, $\mathrm{Fe}-\mathrm{Ni}$ $\mathrm{P}$ 合金皮膜は非晶質化しやすくなる。

このように，Fe-Ni-P合金の場合，皮膜の非晶質化に 必要な P含有量が減少することはHEDPの結晶微細化 への促進と $\mathrm{Fe}$ の合金化の二つの役割からであることが 分かる。

更に，以上の結果並びに HEDP浴で得られた種々の 組成の Fe-Ni-P合金膜のX線回折図形から，合金組成 と皮膜の非晶質条件との関係を図10にまとめて示す。こ の図から，アルカリ性 HEDP浴で作製した Fe-Ni-P合 金膜は $4 \sim 12 \mathrm{wt} \% \mathrm{P} ， 0 \sim 60 \mathrm{wt} \% \mathrm{Fe}$ の範囲で非晶質構 造を取ることが分かる。 


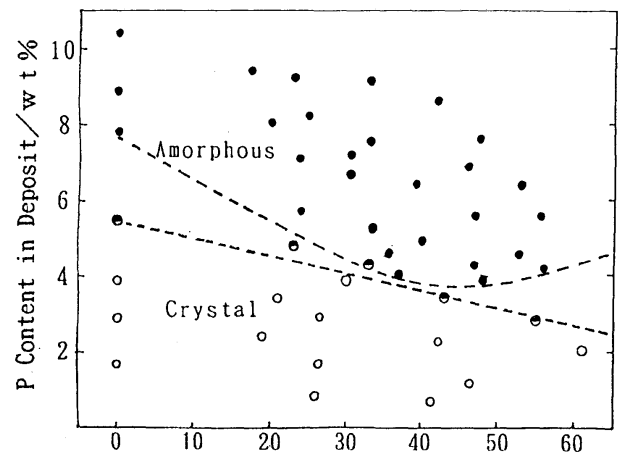

Fe Content in Deposit / w t \%

- Amorphous, $\theta$-Amor. +Cry., O-Crystal

Fig. 10 Relationship between the alloy structure and the composition.

\section{4. 結果}

電析法により, HEDPのアルカリ性浴からの Fe-Ni$\mathrm{P}$ 非晶質合金膜の作製を検討した結果，次のことが明ら かとなった。

(1) 電析法により, HEDPのアルカリ性浴を用いて, 広 い範囲の電解条件下で良好な光沢性, 均一性を有する $\mathrm{Fe}-\mathrm{Ni}$-P非晶質合金膜が作製できる。

(2) 通常の鉄及び鉄合金めっきでは浴中の第二鉄が皮膜 の光沢性及び組成に著しく影響するが，HEDP浴の場 合，第一鉄浴と第二鉄浴のいずれでも得られた皮膜の光
沢性と組成はほぼ類似する。

（3）実験した浴組成と電析条件の範囲で，浴中の金属イ オン総量が $20 \mathrm{~g} /$ L以内で非晶質皮膜を作製することが できる。

(4) HEDPは表面活性があるので, 結晶を微細化させ, 皮膜の非晶質化に必要な P含有量が少し低下する。また は皮膜の Fe含有量が $60 \mathrm{wt} \%$ 以下では，Fe-Ni-P合金膜 の非晶質化の P限界含有量屯 7.6wt\%から $5 \mathrm{wt} \%$ 程度 まで減少する。

(1992-12-16 受理)

\section{文献}

1）増井寛二，山田敏夫，久松敬弘 ; 金属表面技術，32，410 (1981)

2 ) 田中道夫 ; 金属材料, 16, 58 (1976)

3 ）泉 久司, 砂田久吉, 近藤幸夫, 山崎 徹 ; 日本金属学会 誌, 44, 829 (1980)

4) A. Brenner, D. E. Couch and E. K. Williams ; Plating, 37, 36 (1950)

5 ) 奈賀正明, 橋本功二, 増本 健 ; 日本金属学会誌，38, 835 (1974)

6 ）古川直治，林 忠夫 ; 金属表面技術，37，67（1986）

7 ）菅沼葉二，後藤文男，逢坂哲彌 ; 金属表面技術，34，254 (1983)

8 ）高 娟, 沼田博雄, 大野 湶, 春山志郎 ; 表面技術, 40, 431 (1989)

9）方 景礼 ; 多元絡合物電鍍, p.273（国防工業出版社，1983）

10）高 学鋒，傳 燕雲，小若正倫; 表面技術，43，160（1992）

11）増井寛二，立原三樹，山田敏夫 ; 日本金属学会誌，44，124 (1980) 